\title{
Russian Neo-Kantianism of Fyodor Stepun and Sergius Hessen: Features of the Philosophy of Culture
}

\author{
Anna Chernysheva \\ Department of Sociology and Cultural Studies \\ Bauman Moscow State Technical University \\ 5/1, 2nd Baumanskaya St. \\ Moscow, Russia 105005 \\ E-mail: irida64@bk.ru
}

\author{
Anna Kostikova \\ Lomonosov Moscow State University \\ Leninskie gory 1 \\ Moscow, Russia 119991 \\ E-mail: akostikova04@yandex.ru
}

\begin{abstract}
The article presents an analysis of the features of the philosophy of culture in abroad Russian Neo-Kantianian tradition, most fully presented in the works of F. A. Stepun and S. I. Hessen. Following the German predecessors, the Russian Neo-Kantians considered values as a key problem of philosophy of culture. Neo-Kantianian tradition derived from Kant's ideal of knowledge emphasized the idea of "philosophy with special knowledge", and incorporation "not only the fullness of special scientific motives, but also the motives of other areas of culture - the public, art and religion." The diversity of modern interpretation of philosophy of culture is due to different definitions of cultural values and to its continuing emphasis on cultural policy.
\end{abstract}

Keywords-Neo-Kantianism; philosophy of culture; history of philosophy; metaphysics; theory of knowledge; experience; cultural values; axiology; creativity

\section{INTRODUCTION}

The philosophy of culture continues to play a fundamental role in the structure of modern cultural knowledge. It provides a choice of cognitive orientations of cultural studies, giving the opportunity to interpret the nature of culture in a variety of ways. Acting as a general theory of culture the philosophy of culture identifies the essence of culture and its difference from nature in studying the structure, functions, roles of culture, the leading trends in its development. Philosophy of culture proposes the analysis of essential features of culture - as the senses of human being, determining human existence.

The foundations of modern philosophy of culture laid in the second half of the XIX century by different schools of European philosophy. One of the prominent is Neo Kantianism (G. Cohen, P. Natorp, E. Cassirer, W. Windelband, H. Rickert). To the study and analysis of this philosophical and cultural inquiries, Russian followers and Contemporain European trends of Kant's philosophy interpretations is given enough space in domestic research literature [1] [2] [3] [4] [5] [6] [7] [8] [9] [10] [11]. The converse reading of transcendental philosophy and its features for modern culture is shown in recent works - for example, J-L.Nancy [12]. In our opinion, in the existing Russian- language research is paid very little attention to the
Russian Neo-Kantian issues for the philosophy of culture. For example, N. Dmitrieva's monography "Russian NeoKantianism: "Marburg" in Russia" is focused on the influence of the Marburg school on Russian culture and the emancipation of the critical philosophy in Russian thought [13]. V. N. Belov's article "Russian Neo-Kantianism: history and features of development" examines the history of the specific development of Neo-Kantianism in Russia based on the examples of A. I. Vvedensky, B. V. Yakovenko and V. E. Sazeman [14]. The exception are the O. V. Chernyavskaya's article "Transcendent philosophy of culture of Sergey Iosifovich Hessen" with the analysis of Hessen's concept of culture threw the transcendental grounds of personality, formed in the process of its introducing to the world of transcendental values [15] and one of author's article [16] But the diversity of Russian Neo-Kantianian conceptions of culture is still not in the focus of historical reconstruction.

\section{II. “LOGOS": PRE-EXPERIMENTAL VALUES}

Philosophy of culture of Russia Neo-Kantianism are conceptualised under the influence of $\mathrm{H}$. Rickert, and the main merit in the development of philosophical and cultural ideas in this framework belongs to the members of the editorial Board of the journal "Logos" [17] [18]. NeoKantian understanding of culture is based on the activity of the human subject. Culture here is a area, generated by the human being, even if it is based on a priori values, constituting human existence. This new ontology - ontology of the subject - is being built; the boundaries of semantic space are determined by philosophical systems from $\mathrm{R}$. Descartes to I. Kant, and vice versa. Rationalism is understood primarily as a mechanism of correspondence that carries out the cognition to the subject of cognition: "mind" a "measure" of the content of the subject in the object. The crisis of culture in this case is a crisis of relations between the subject and the object, the collapse of the "forms", "types" and "ways" of these relations. The task of its overcoming becomes the ordering of the relations of subject and object on the basis of strengthening a "knowledge" that, from the point of view of Neo-Kantians, is developed, on the one hand, epistemological perspectives, and on the other through the desire of relativization (proposed by the most visionary Neo-Kantians). A. I. Vvedensky, G. I. Chelpanov, 
B. P. Vysheslavtsev, F. A. Stepun, B. and V. Yakovenko tried to realise this desire in different versions of metaphysical searches [19] [20].

Russian Neo-Kantians examine thoroughly the structure of "experienced" knowledge and quite early (as A. I. Vvedensky) realize that the relationship of cause and action cannot be fully understood in a rational way. As a consequence, very important becomes the intention to root the knowledge in an ideal existence, which is understood if not as a metaphysical reality, then as a logical condition of knowledge existing outside and before the subject. This is the source of the Neo-Kantian's interpretation of the concept of "logos", which gave rise to an active debate about the name of the journal" Logos" - the mouthpiece of this direction of thought [21]. In this regard, some Neo-Kantians tend to "Hume's" and "Fichte's" reading of Kant that leads them to the statement of the impossibility of identifying a "pure I" with experience. Culture is considered as a special area of "pre-experimental" existence, in which through values a person acquires the transcendental basis of his life and understands it and himself outside the subject-object dichotomy. The topos of understanding the actual cultural problems in Neo-Kantianism, therefore, - are "values" and the way to correspond with in every phenomenon.

\section{FYODOR STEPUN: VALUES AS CREATIVITY}

As editors and publishers of the Russian version of the international journal "Logos" (1910-1914), Russian NeoKantians in the Preface to its first issue emphasize the scientific nature of their philosophy, which is considered by them as "rational knowledge leading to scientifically accessible unity". According to this formula, "philosophy is the most delicate flower of the scientific spirit." They emphasize the independent and self-sufficient importance of philosophical knowledge. However, proclaiming the "principle of autonomy of philosophy", the editors of "Logos" consider it necessary to link the "philosophical tradition with the fullness of special knowledge", at the same time, without dissolving philosophy in science as positivism did. Speaking for the union of "philosophy with special knowledge", they consider at the same time the necessity that "philosophical thought incorporates not only the fullness of special scientific motives, but also the motives of other areas of culture - the public, art and religion." The task of the Logos is "to develop all these areas by scientific and philosophical method, the requests and needs of which should receive proper philosophical satisfaction". Collections of "Logos" are defined "as collections on the philosophy of culture," opposing the contemporary cultural decay.

The authors of the Preface recognize the "national characteristics of philosophical development", they envision one of the main tasks of the Russian edition of "Logos" in the "introduction the Russian culture and its original motifs to the overall culture of the West" and promised "to keep the Russian reader up to date with modern teachings of the West" [22]. Due to its Pro-Western orientation, Logos was rejected by the Slavophile tradition and some supporters of religious philosophy. The centre of opposition was the publishing house "Way", which published works of religious philosophers. FA Stepun remembered the words N. Ah. Berdyaev, who expressed the original essence of the differences between the "Logos" and the "Way": "for you, he attacked me - religion and the Church are the problems of culture, for us, culture in all its manifestations is an internal Church problem. You want to come to God on the philosophical ways, but I claim that you cannot come to God, you can only proceed from him: and, only on the basis of God, you can come to the correct, i.e. Christian, philosophy".

Subsequently, however, we can see a sort of convergence between "logos-men" and "way-men". F. A. Stepun selfcritically admits: "Philosophizing "from childhood" we were ready "to cut hair and nails" to Moscow Slavophil. I will not say that we were wrong in everything, but we started very confidently for the reform of the style of Russian philosophy." "I, he said of his philosophical evolution, and to a lesser extent Hessen largely very much closer to its former Moscow opponents" [23]. Philosophical views of F. A. Stepun are a kind of synthesis of Neo-Kantianism and romanticized "philosophy of life" with religious philosophy in the spirit of V. S. Solovyov. Many contemporaries did not see such a synthesis organic, but it is indicative of the mentality of a certain current of Russian philosophical thought. The logic of such a heterogeneous construction is described by him in the essay "Life and Work" (1913) - the main conceptual work of the philosopher.

F. A. Stepun claims that "the only true task of philosophy" is "beholding the absolute" [24]. Kant's criticism characterizes, as F.A. Stepun argues, the modern level of scientific philosophy. But even this form of theoretical experience is determinated by life circumstances: "...lived not Kant in Konigsberg, but in Siberia, he probably would have realized that the space is not phenomenal, but ontological" [25]. In other words, space objectively exists, and is not a form of human sensuality, as Kant teaches.

His reasoning about the life and creativity F.A. Stepun begins with the concept of experience as a basis, meaning not a specific subjective-mental feeling, but a certain "experience" in General, the two poles of which are life and creativity. At the same time, the experience-life is a "mystical experience" because the notion of life "is the concept of "positive unity"" [26]. So, F. A. Stepun is trying to combine the "philosophy of life" with the teachings of V. Solovyov, and to "cross" V. Solovyov with I. Kant: for him positive unity is not "the absolute itself", but only "a logical symbol of this absolute, and even then, not absolute as it is actually in itself, but as it is given in the experience." However, this very "experience of life" is postulated "as a religious experience, as a religious experience of God". Thus, the "knowledge of Life" is equivalent to knowledge of "the living God" [27]. Creativity is considered by the philosopher as an experience opposite to the experience of life. If the experience of life is characterized as "positive unity", then there is no unity in the experience of creativity. It is divided into the subject and the object and breaks up into various forms of cultural creativity: science, philosophy, art, religion.

F. A. Stepun distinguishes "the values of the state" and. "The values of the state" are the values in which each person 
is organized (with the value of the individuality as the first one) and the "values in which the hole humanity is organized (with the basic value of fate). "The values of the state" "- the second level of values of creativity. These include the values of scientific and philosophical and aesthetic and Gnostic. "Scientific and philosophical values are those that build the cultural goods of exact science and philosophy... Aesthetically-Gnostic values are those that build cultural benefits of art and symbolically-metaphysical system of philosophy" [28].

The creative beginning of the personality of F. A. Stepun was expressed in his works (in 1923 he published the philosophical novel "Nikolai Pereslegin"), his memories "Former and Unfulfilled" have not only documentary, but also artistic significance, and the deep interest in literary and theatrical creativity he realises in "The Meetings" which contains articles and essays about A. S. Pushkin, L. N. Tolstoy, F. M. Dostoevsky, V. F. Komissarzhevskaya, M. N. Ermolova, I. A. Bunin, Vyacheslav. Ivanov, A. A. Blok, B. Zaitsev, B. Pasternak [29]. According to F. A. Stepun, the relationship between life and creativity is contradictory. He proclaims the "uniform recognition of both poles" - "as the pole of Life, and the pole of Creativity." At the same time, he believes "that Life is God, and creation is a falling away from It" [30]. At the same time, creativity "cannot be meaningfully and rejected as a sinful and godless selfaffirmation of man. By creating, man obediently accomplishes its truly human, i.e., specified to him by God duty" [31]. This ambivalent relationship of art to Life-to God is "the tragedy of creativity", which the philosopher in the article "Tragedy of Creativity (Friedrich Schlegel)" (1910) describes as the quest to solve the impossible task: "to hold the life itself into the creativity" [32]. Cultural values are concerned as a challenge for the human being.

\section{Sergius Hessen: Cultural VAlues as SuPER INDIVIDUAL}

S. I. Hessen in his philosophical views, is a follower of the Baden school of Neo-Kantianism. Like his teacher $\mathrm{H}$. Rickert, he highlights above all, the problem of values. In the article "Mysticism and Metaphysics" (1910) S.I. Hessen defines philosophy "as the science of values," and aesthetics as "the study of aesthetic values" [33]. However, if in this work he still shares the view of H. Rickert on the" dualism of value and existence "and defines the value itself as the" minimum of transcendent existence", then in the following" Philosophy of punishment " (1912-1913) the value is understood more specifically. Applying the concept of value to legal issues, S. I. Hessen interprets the value quite concrete - here and now. Believing that the life and the consciousness are indifferent to values, he believes that "without this material basis, values remain significant in the air". In his work "Fundamentals of pedagogy. Introduction to applied philosophy"(1923) the philosopher states that "the world could not be reduced to physical and mental reality, that in addition to the physical and to the mental there is a third Kingdom in the world, the Kingdom of values and sense, in which, along with the forms of knowledge is in its eternal purpose - the freedom of human being" [34].
According to S.I. Hessen's belief, the cultural values to which he refers science, art, morality, religion, law, statehood, economy, technology, - are "serving as the tools of another, ... besides all are also valuable in themselves. In this sense, we call them absolute values." "Kingdom of values" for S.I. Hessen is a spiritual sphere: "the set of cultural values we call ancient, somewhat ambiguous, but still a wonderful name of the Spirit" [35]. The values of culture are 'super individual'.

From this theoretical and value point of view, S. I. Hessen considers the phenomenon of law and legality. For him, crime and punishment are not just facts; they are events that require understanding "from the point of view of their (legal) meaning, sense, value". This value-legal position leads him to a negative attitude to the death penalty, which he considers incompatible with the "act of justice", since it destroys the "legal entity", and therefore "the murder of a person sentenced to death is the same crime as the murder of any citizen" [36]. Neo-Kantian position has still very influence for philosophical research in the field of free will and justice [37].

In this theoretical and value aspect, the philosopher interprets the central pedagogical problems. Stressing "the idea of unity of a psychophysical organism, equal sides of which are mutually intertwining mental and physical processes", S. I. Hessen is convinced that "the soul and the human body should be equally formed in the direction of cultural values, in relation to which they, as a purely natural material to be formed, are represented as equal sides of a single and indivisible whole. The whole person as a whole and not only one part or side, have to absorb the values of culture, to join those values with the whole being and to serve them in transforming its psycho-physical organism" [38].

Like many other Russian thinkers, in his creative activity, S. I. Hessen shows great interest in Russian literature, especially to F. M. Dostoevsky, in whose works he sees artistically expressed philosophy and genuine humanism. The true humanism, according to, supposing "humility before Absolute" and the awareness of the limitation of human mind in the spirit of Kant's philosophy. The culture is for S. I. Hessen the mindset of "love, and not love to the distant, too often turns into disgust and hatred of the neighbour, but love to the concrete, to the living, to the individual" [39]. We could add that this interpretation of cultural phenomenon includes the opportunity to compare the efficiency of cultural emancipations.

\section{CONCLUSION}

For Russian Neo-Kantians, as well as for their German predecessors, the key problem of the philosophy of culture is the problem of values, which, however, is considered in different ways [40]. F. A. Stepun refers to the values of culture broadly understood "the experience of life" and "the experience of creativity". For S. I. Hessen the products of creativity only can be considered as cultural values. The life is only the basis and the condition of the possibility of culture. As it was shown the converse understanding of 
cultural values emphasize the converse reading of in-abroad Russian philosophical tradition.

\section{REFERENCES}

[1] Belov V. N. Russian Neo-Kantianism and Russian religious philosophy: an attempt at comparative analysis. Russian philosophy: unity and diversity. Saratov, Saratov University Press, 2010.

[2] Belov V. N. Russian Neo-Kantianism: history and features of development. Kant's collection, 2012, № 1 .

[3] Belov V. N. The problem of rational and irrational in Russian neoKantianism. Spiritual continent of Russian philosophy. Saratov, Saratov University press, 2009.

[4] Belov V. N. The doctrine of Hermann Cohen in Russia: peculiarities of the reception. German and Russian neo-Kantianism: between the theory of knowledge and criticism of culture. Moscow, Russian political encyclopedia (ROSSPEN), 2010.

[5] Belov V. N. Philosophy of Hermann Cohen and Russian neoKantianism. Historical and philosophical Yearbook-2003. Moscow, Nauka, 2004.

[6] Dmitrieva N.A. Russian Neo-Kantianism: "Marburg" in Russia. Historical and philosophical essays. Moscow, Russian political encyclopaedia (ROSSPEN), 2007.

[7] Rumyantseva M. F. Russian version of neo-Kantianism: to the problem statement. Scientific notes of Kazan University. Vol. 154. kN. 1. 2012.

[8] Chernyavskaya O. V. Transcendental philosophy of culture of Sergey Iosifovich Hesse. Historical, philosophical, political and legal Sciences, cultural studies and art history. Theory and practice. Tambov, Diploma, 2013, № 8, part 2, p. 203-205.

[9] Sokuler Z.A. Hermann Cohen and the philosophy of dialog. M.: PROGRESS-TRADITION, 2008.

[10] Kostikova, A. A. Sade-sation of Kant's philosophy as a trend of modern philosophy // History of philosophy: issue 1: Kant and modernity. - Vol. 1. - Modern notebooks Moscow, 2005. - P. 246-250.

[11] Chernysheva A.V. Philosophy of culture of Russian neo-Kantianism / / Russian philosophical thought: in Russia, in Russia and abroad: Collection of scientific articles. - Moscow: publishing House of Moscow University, 2013. P. 429-439.

[12] Nancy J.-L. La Tradition allemande dans la philosophie, dialogue avec Alain Badiou, Édition et postface de Jan Völker, Paris, Éditions Lignes, 2017.

[13] Dmitrieva N.A. Russian Neo-Kantianism: "Marburg" in Russia. Historical and philosophical essays.

[14] Belov V. N. Russian Neo-Kantianism: history and features of development.

[15] Chernyavskaya O. V. Transcendental philosophy of culture of Sergey Iosifovich Hesse.

[16] Chernysheva A.V. Philosophy of culture of Russian neo-Kantianism.

[17] Ern V. F. The Struggle for the Logo. Compositions. Moscow, Truth, 1991.

[18] Zenkovsky V. V. History of Russian philosophy. Vol.1. Part 1. Leningrad, Academic project, 1991.

[19] Lossky N. Oh. History of Russian philosophy. Moscow, Soviet writer, 1991.

[20] Hessen S. I., Stepun F. A. From the editorial Board (Goals and objectives of modern philosophical thought). Russian philosophy. Late XIX-early XX century. Anthology. St. Petersburg, Hansa, 1993.

[21] Zenkovsky V. V. History of Russian philosophy. Vol.1. Part 1

[22] Stepun F. A. The Former and the Unfulfilled. St. Petersburg, St. Petersburg University publ., 1997, p. 423-431.

[23] Ibid., p.218-219.

[24] Stepun F. A. Life and creativity. Russian philosophers (late nineteenth - mid twentieth century): an anthology. Issue. 2. Moscow, Book chamber, 1994, p. 141
[25] Stepun F. A. The Former and the Unfulfilled, p. 264

[26] Stepun F. A. Life and creativity, p.157-160.

[27] Ibid., p. 179-180.

[28] Ern V. F. The Struggle for the Logo. Compositions, p. 171.

[29] Stepun F. A. Meetings. Moscow, Agraf, 1998

[30] Stepun F. A. Life and creativity, p.181-182.

[31] Stepun F. A. The Former and the Unfulfilled, p. 182.

[32] Ern V. F. The Struggle for the Logo. Compositions, p.194

[33] Hessen S. I. Mysticism and metaphysics. Logo. Vol. 1. Moscow, A. Levenson printing House, 1911, p. 133, 125.

[34] Hessen S. I. Fundamentals of pedagogy. Introduction to applied philosophy. Moscow, SHKOLA-Press, 1995, p. 248-249.

[35] Hessen S. I. the Problem of legal socialism. End. Modern notes. XXXI. Paris, 1927, p. 32, 376.

[36] Hessen S. I. Mysticism and metaphysics. Logo. Vol. 1, p. 228-229.

[37] Kostikova A. A. Modern philosophy: a new approach to research, teaching, development (review of research experience of analytical philosophy of consciousness) in the journal Vestnik of Moscow University. Series 7: Philosophy, Moscow publishing house. UN-TA / / Bulletin of Moscow University. Series 7: Philosophy. - 2016. - Vol. 1. - P. 77-85.

[38] Hessen S. I. Fundamentals of pedagogy. Introduction to applied philosophy, p.376.

[39] Hessen S. I. the Problem of legal socialism. End. Modern notes, p. 353.

[40] Chernysheva A.V. Formation of philosophy of culture in Russia. From Chaadayev to the present day // Saabruecken, Germany: LAP LAMBERT Academic Publishing GmbH, 2011. 